\title{
DECISIONS
}

\section{Intermittent allergic rhinitis}

\section{Gordon Sussman MD, David Sussman, Arthur Sussman MD}

Previously published at www.cmaj.ca

\begin{abstract}
A 20-year-old woman presents with nasal congestion and a runny nose that occur in the late spring and early fall and are occasionally associated with wheezing and asthmatic symptoms. She also has itchy, watery eyes and an itchy palate. Her symptoms begin in April through June, disappear in July and return in late August and September. During these times, her symptoms occur daily with episodes of repeated sneezing and constant nasal congestion. The symptoms interfere with her gardening, job and sleep. She has had to miss 10 days of work this year. Toward the end of September, she notes that her wheezing and asthmatic symptoms are more severe. She has had these symptoms since childhood, but over the last three seasons, the intensity of the symptoms has become more severe. She has taken over-the-counter antihistamines, but they are not effective.
\end{abstract}

\section{Does this patient have intermittent allergic rhinitis?}

Our patient is presenting with characteristic symptoms of seasonal rhinitis, or hay fever, which is now termed intermittent allergic rhinitis ${ }^{1-3}$ - an IgE-dependent allergy caused by airborne allergens, including pollens. It is part of a more complex systemic disease that may involve asthma, sinusitis or oral allergy syndrome. It affects more than $20 \%$ of the population in Western societies. ${ }^{4}$ The diagnosis of intermittent allergic rhinitis is usually straightforward, but it requires a systematic approach based on history, physical examination and, when indicated, other special testing. ${ }^{1}$

Symptoms associated with intermittent allergic rhinitis can vary among patients. Generally, the symptoms encompass nasal (e.g., itching, sneezing, rhinorrhea), sinus-related (e.g., congestion, postnasal drainage, headache), conjunctival (pruritis, red or teary eyes) and asthmatic (cough, wheeze, shortness of breath) complaints that may present intermittently or persistently throughout the year.

Although allergic rhinitis is frequently trivialized and underdiagnosed, the constellation of symptoms associated with it may have a substantial negative impact on a person's overall quality of life and performance at home, school or work. ${ }^{1,4}$

\section{Are any tests required?}

Our patient's symptoms occur in the seasons for tree pollen (spring) and ragweed pollen (fall), and the clinical manifestations are characteristic of allergic rhinitis, conjunctivitis, pharyngitis, sinusitis and asthma. She should undergo skin prick testing for the allergens specific to the regional area.
A skin prick test can be used to detect allergen-specific $\mathrm{IgE}$ and confirm the diagnosis of allergic rhinitis. The test should assess allergens likely to be of clinical significance for example, animal dander, pollen, grass, dust mites and mould. Generally, negative results of skin prick tests with proper negative and positive controls exclude IgE-mediated disease. Immunoassays for serum-specific IgE, though costly, can be used as an alternative. A total IgE level is nonspecific and is not needed in the diagnosis of allergic rhinitis. ${ }^{4.5}$

A patient whose symptoms occur annually is likely to be reacting to seasonal pollen or other environmental triggers. In Canada, the season for tree pollen can vary from April to mid-June, and that for ragweed pollen (absent on the west coast) is usually from the second or third week in August until the frost. Other allergens for which patients with seasonal symptoms are tested include grass pollens (occurring from June to July) and common moulds (year-round). Occasionally, patients with allergies to dust mites will present seasonally because of the increased humidity in their homes. Physicians should be cognizant of any changes in a person's home or work environment (e.g., a new pet). A history of asthmatic complaints should be confirmed by pulmonary function testing. ${ }^{1.4,5}$

The use of flexible and rigid endoscopy as well as computed tomography for the nose and paranasal sinuses may be considered in patients with atypical clinical presentation of symptoms (e.g., unilateral rhinorrhea) or for those who do not respond well to conventional medical treatments.

\section{How severe are the allergies?}

The ARIA guideline (Allergic Rhinitis and its Impact on Asthma, ${ }^{1}$ available at www.whiar.org) is an evidence-based standard for classifying and treating patients with respiratory allergies (Table 1). ${ }^{2,3,5}$ It can be used to categorize patients based on the severity and persistence of the rhinitis. The rhinitis is classified as mild, moderate or severe depending on the severity of the symptoms and quality of life.

Our patient presents with severe intermittent symptoms in spring and early fall, as well as constant nasal symptoms,

From the Department of Medicine (G. Sussman), University of Toronto, and the Division of Allergy, Clinical Immunology, St. Michael's Hospital; University of Toronto (D. Sussman); and Mount Sinai Hospital (A. Sussman), Toronto, Ont.

CMAJ 2010. DOI:10.1503/cmaj.091490 
including congestion and rhinosinusitis. Her quality of life, including her work and sleep, is limited for a few months of the year. Given these symptoms, this patient would be categorized as class III.

\section{What treatment should be offered?}

Treatment of allergic rhinitis is categorized into strategies to avoid allergens, pharmacotherapy and immunotherapy (Table 2 ). Since our patient has class III allergies, she would be given strategies to avoid allergens and pharmacotherapy.

Orally administered nonsedating $\mathrm{H}_{1}$ antagonists and nasal steroid sprays are the mainstay of treatment for intermittent allergic rhinitis. These classes of medication are effective and safe;, 45 treatment failure may result from poor compliance of the patient or the use of improper technique.

Oral treatment with $\mathrm{H}_{1}$ antagonists is effective for conjunctival and nasal symptoms but not for nasal congestion. Treatment with nasal steroids is superior for nasal allergy symptoms, including nasal congestion. ${ }^{5,6}$ It is common for patients with rhinitis to have coexisting sinusitis and asthmatic symptoms. Adequate treatment of allergic rhinitis is fundamental for the overall treatment of these associated conditions. ${ }^{1,4}$ In patients with intermittent allergies, pharmacologic treatment should be started before seasonal exposure and be maintained to the end of the season.

Allergen immunotherapy is the only long-term modulatory treatment for allergic rhinitis. It should be considered for patients with moderate-to-severe symptoms (class II or III) or for those who have not responded to pharmacotherapy or optimal measures to avoid allergens. Immunotherapy is available for patients with allergies to tree, grass and ragweed pollen. Standardized aqueous immunotherapy vaccines can be used year-round to manage persistent allergic rhinitis. Immunotherapy may induce long-term

Table 1: Classification of rhinitis*

\begin{tabular}{|c|c|c|}
\hline Class & Severity and duration & Symptoms \\
\hline I & Mild, intermittent & $\begin{array}{l}\text { Nasal rhinorrhea } \\
\text { Sneezing } \\
\text { Itchy, watery eyes }\end{array}$ \\
\hline II & $\begin{array}{l}\text { Moderate, intermittent } \\
\text { Moderate-severe, } \\
\quad \text { intermittent } \\
\text { Severe, intermittent } \\
\text { Mild, persistent }\end{array}$ & $\begin{array}{l}\text { More severe than those } \\
\text { for class I }\end{array}$ \\
\hline III & Moderate, persistent & $\begin{array}{l}\text { Constant nasal stuffiness } \\
\text { Severe, limiting quality of } \\
\text { life }\end{array}$ \\
\hline IV & $\begin{array}{l}\text { Moderate-severe, } \\
\text { persistent } \\
\text { Severe, persistent }\end{array}$ & $\begin{array}{l}\text { Severe ongoing nasal } \\
\text { stuffiness } \\
\text { Congestion } \\
\text { Sinus drainage }\end{array}$ \\
\hline
\end{tabular}

*Source: Small and colleagues. ${ }^{2}$

†Based on ARIA (Allergic Rhinitis and its Impact on Asthma) guidelines: ${ }^{1}$ mild $=$ no change in quality of life; intermittent $=<4 \mathrm{~d} / \mathrm{wk}$ or $<4 \mathrm{wk}$; moderatesevere symptoms = impairment of daily activities (one or more of sleep, work, school, troublesome symptoms); persistent $=>4 \mathrm{~d} / \mathrm{wk}$ or $>4 \mathrm{wk}$. remission and prevent new sensitizations and the progression to asthma. ${ }^{6-9}$

Endoscopic surgery (e.g., to open sinus ostia and air cells) may be used in patients with chronic sinusitis who do not respond to conventional pharmacologic treatment. ${ }^{10}$ There is also a role for recently developed immunomodulating biologic medications (e.g., omalizumab) in patients with moderate to severe asthma. ${ }^{11}$

\section{Will the symptoms worsen over time?}

Our patient's symptoms may become more prolonged or severe ${ }^{1,4}$ Her condition could progress to include reactions to other allergens (e.g., cat and dog dander) or birch/ragweedfood syndrome (i.e., oral allergy syndrome), which has been reported in $50 \%$ to $70 \%$ of adults with allergic rhinitis. ${ }^{12}$ Other associated conditions include more prolonged sinusitis and asthma. Many patients underestimate the potential seriousness

Table 2: Treatment options for allergic rhinitis*

\begin{tabular}{|c|c|}
\hline Classt & Treatment \\
\hline I (mild, intermittent) & $\begin{array}{l}\text { - Cromolyn sodium } \\
\text { - Oral or topical antihistamine } \\
\text { - Intranasal decongestant } \\
\text { - } \quad<10 \mathrm{~d} \text { ) or oral decongestant } \\
\text { - Strategy to avoid allergens }\end{array}$ \\
\hline $\begin{array}{l}\text { Il (moderate-severe, } \\
\text { intermittent; mild, } \\
\text { persistent) }\end{array}$ & $\begin{array}{l}\text { - Specific immunotherapy } \\
\text { - Intranasal corticosteroid } \\
\text { - LTRAs } \\
\text { - Cromolyn sodium } \\
\text { - Oral or topical antihistamine } \\
\text { - Intranasal decongestant } \\
\text { - } \quad \text { Strategy to avoid allergens }\end{array}$ \\
\hline III (moderate, persistent) & 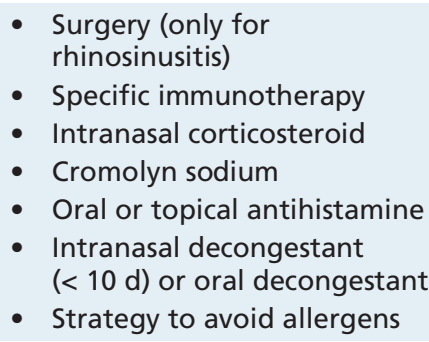 \\
\hline $\begin{array}{l}\text { IV (moderate-severe, } \\
\text { persistent) }\end{array}$ & $\begin{array}{l}\text { - } \text { Oral steroids§ } \\
\text { - Surgery (only for } \\
\text { rhinosinusitis) } \\
\text { - Specific immunotherapy } \\
\text { - Intranasal corticosteroid } \\
\text { - } \text { Oral or topical antihistamine } \\
\text { - } \text { Intranasal decongestant } \\
\text { - } \quad \text { Strategy to avoid allergens }\end{array}$ \\
\hline
\end{tabular}

Note: LTRA = leukotriene receptor antagonists

*Source: Small and colleagues. ${ }^{2}$

tFor each subsequent class, step up treatment if there is no response or incomplete response.

FLTRAs may be used in class III and IV, but there is less supporting evidence. §Oral steroids should only be used in the short term; they may be considered for class II, but there is less supporting evidence. 
of their chronic symptoms; allergic rhinitis is a highly prevalent condition that exacts a high cost in terms of illness, loss of productivity and use of health care resources. ${ }^{6}$ Although there is no real means of prevention, patients should be educated about how to avoid allergens and receive appropriate pharmacotherapy and, when required, immunotherapy to effectively prevent the development of associated illnesses and new sensitizations and the progression to asthma.

This article has been peer reviewed.

Competing interests: None declared.

\section{REFERENCES}

1. Bousquet J, Khaltaev N, Cruz A, et al. Allergic Rhinitis and its Impact on Asthma (ARIA). Allergy 2008;63(Suppl 86):8-160.

2. Small P, Frenkiel S, Becker A, et al. Rhinitis: a practical and comprehensive approach to assessment and therapy. J Otolaryngol 2007;36(S1):S5-S27.

3. Demoly P, Allaert F, Lecasble M, et al. Validation of the classification of ARIA Allergy 2003;58:672-5.

4. Adkinson $\mathrm{F} \mathrm{Jr}$, Bochner $\mathrm{B}$, Busse $\mathrm{W}$, et al. Middleton's allergy principles and practice. 7 th ed. St. Louis (MO): Mosby Elsevier; 2009.

5. Plaut M, Valentine M. Allergic rhinitis. N Engl J Med 2005;353:1934-44.

6. Rosenwasser, L. Treatment of allergic rhinitis. Am J Med 2002;113:17-24

7. Durham SR, Walker SM, Varga EM, et al. Long-term clinical efficacy of grasspollen immunotherapy. N Engl J Med 1999;341:468-75.

8. Plaut M, Rotrosen D. Tolerance induced by allergen immunotherapy. In: Lockey
RF, Bukantz SC, Bousquet J, editors. Allergens and allergen immunotherapy. 3rd ed. New York (NY): Marcel Dekker; 2004. p. 681-702.

9. Moller C, Dreborg S, Ferdousi HA, et al. Pollen immunotherapy reduces the development of asthma in children with seasonal rhinoconjunctivitis (the PAT-study). $J$ Allergy Clin Immunol 2002;109:251-6.

10. Poetker DM, Smith T. Adult chronic rhinosinusitis: surgical outcomes and the role of endoscopic sinus surgery. Curr Opin Otolaryngol Head Neck Surg 2007; 15:6-9.

11. Molimard M, de Blay F, Didier A, et al. Effectiveness of omalizumab (Xolairs) in the first patients treated in real-life practice in France. Respir Med 2008;102: 71-6.

12. Bircher AJ, Van Melle G, Haler E, et al. IgE to food allergens are highly prevalent in patients allergic to pollens with and without symptoms of food allergy. Clin Exp Allergy 1994;24:367-74.

Decisions is a new series that focuses on practical evidencebased approaches to common presentations in primary care. The articles address key decisions that a clinician may encounter during initial assessment. The information presented can usually be covered in a typical primary care appointment. Articles should be no longer than 650 words, should include one box, figure or table and should begin with a very brief description ( 75 words or less) of the clinical situation. The decisions addressed should be presented in the form of questions. A box providing helpful resources for the patient or physician is encouraged.

\section{CMAJ celebrates}

\section{0 years \\ in 2011!}

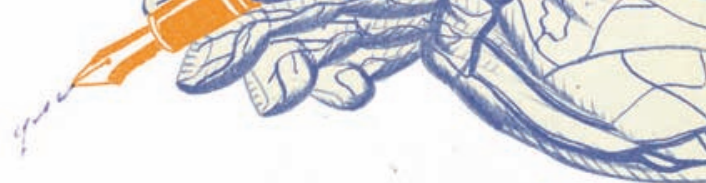

Visit www.cmaj.ca

We want to hear from you. Tell us how CMAJ affected your practice or your life, recollect coincidences, controversies or quirky content...

Send to 100years@cmaj.ca or Carole Corkery, CMAJ, 1867 Alta Vista Dr., Ottawa ON K1G 5W8
When you treat $\mathrm{MDD}^{*}$ is your mission just remission?

\section{Or do you aim for more?}

${ }^{*}$ Major depressive disorder

Wyeth

(c) 2010 Wyeth Canada, owner, now a part of Pfizer Inc. Montreal, Canada H4R 1J6 